\title{
Stopping Anti-TNF in CD Remitters: Cons
}

\author{
Taku Kobayashi \\ Kitasato University Kitasato Institute Hospital, Center for Advanced IBD Research and Treatment, \\ Tokyo, Japan
}

\section{Keywords}

Infliximab · Adalimumab · Crohn's disease · De-escalation . Inflammatory bowel disease

\begin{abstract}
Crohn's disease may cause a life-long disease burden in many aspects due to its progressive nature. A large proportion of refractory patients have been benefiting from scheduled maintenance anti-TNF treatment; therefore, strategy to stop anti-TNF agents in Crohn's disease is not widely conducted. There have been observational studies demonstrating that approximately half of the patients relapse within a year after discontinuation. Several factors have been suggested as potential predictors for relapse; however, a consensus has not been reached so far. Although most relapse can be rescued by the re-treatment with the same anti-TNF agent, a proportion of patients may result in progressive bowel damage and the need for surgery. Therefore, an attempt to stop anti-TNF is not recommended without careful discussion, even if they are in long-term remission.
\end{abstract}

(c) 2021 The Author(s)

Published by S. Karger AG, Basel

karger@karger.com www.karger.com/iid

Karger"

GOPEN ACCESS
(C) 2021 The Author(s)

Published by S. Karger AG, Basel

This is an Open Access article licensed under the Creative Common Attribution-NonCommercial-4.0 International License (CC BY-NC) (http://www.karger.com/Services/OpenAccessLicense), applicable to the online version of the article only. Usage and distribution for commercial purposes requires written permission.

\section{Introduction}

Crohn's disease (CD) is a type of chronic inflammatory bowel disease. It affects the digestive tract and can cause abdominal pain, diarrhea, fatigue, weight loss, and malnutrition. It may also lead to complications outside the gastrointestinal tract such as arthritis, skin lesions, and uveitis [1]. Therefore, many patients have been suffering from the life-long disease burden; however, the emergence of biologics, namely, the first anti-TNF agent infliximab (IFX), has dramatically changed the clinical course of patients with CD [2]. Anti-TNF agents have been shown to be effective in inducing and maintaining remission [3-5], reducing hospitalizations/surgeries [6], preventing postsurgical relapse [7], and treating extraintestinal manifestations [8]. It has also been shown that the long-term maintenance is more efficacious than episodic treatment [9]. Thus, a significant proportion of patients have been benefiting from the long-term maintenance treatment with anti-TNF agents. Nevertheless, one of the most frequent questions from patients with $\mathrm{CD}$ who have been in long-term remission on anti-TNF agent is whether they can stop it because of their safety concerns, treatment fatigue, and/or financial burden. In general, I do not recommend them to stop it on purpose, and the reasons why stopping anti-TNF is not widely accepted will be discussed in this review.

Correspondence to:

Taku Kobayashi,drkobataku@gmail.com 


\section{Natural History}

$\mathrm{CD}$ is a chronic condition that may affect any part of the entire digestive system. During the last decade, the progressive nature of disease has been increasingly highlighted. Ongoing inflammatory activity may lead to the accumulation of bowel damage, which results in a significant patient burden. Bowel damage includes strictures, fistula, and abscess, which may be irreversible and often require surgery [10]. Indeed, over half of the patients with CD will have structural bowel damage (strictures/fistulae identified by imaging) within 10 years from diagnosis $[11,12]$, and most of these patients will undergo surgery.

Although the current surgery rate is reported to decrease owing to the breakthroughs of the medical treatment including the emergence of anti-TNF agents, nearly $20 \%$ of patients still require surgery within 5 years after diagnosis [13]. It has been also considered that CD rarely burns out over a long period of time, and its inflammatory activity persists $[14,15]$. Overall, the progressive and chronic nature of CD should be carefully taken into account when considering the discontinuation of anti-TNF (or any other ongoing effective treatment) even if the patient is in long-term remission.

\section{Increase of Relapse in Patients Who Stopped Anti- TNF: Observational Studies}

Approximately $20 \%$ of patients per year still lose response even if continuing the treatment $[16,17]$. However, relapse rates following discontinuation of anti-TNF agents reported in clinical studies are higher and increase over time [18-30] (approximately between 30 and 50\%/ year, Table 1). Louis et al. [22] performed a prospective study of 115 patients with CD who were on the combination therapy with IFX and an immunomodulator (IM) for $>1$ year and had been in corticosteroid-free remission for $>6$ months (STORI study), demonstrating that $44 \%$ of patients relapsed within 1 year. These results suggest that discontinuation of anti-TNF is likely to result in relapse in $20-30 \%$ of patients per year based on the difference in relapse rates between patients who continued and discontinued therapy.

A vast majority of patients seem to relapse in the longterm, although such data are available from only a limited number of studies. A Danish retrospective observational study reported a low rate of remission (12\%) at 10 years after the withdrawal of IFX [21]. In the long-term follow- up analysis of the STORI study [31], only $21 \%$ did not require restarting IFX during a median follow-up of 7 years.

Importantly, most studies defined relapse by the symptoms or clinical need for re-introduction of anti-TNF agents; however, recent evidence strongly indicates endoscopic, probably structural, damage precedes the emergence of clinical symptoms [32]. Therefore, there is a concern that irreversible bowel damage could be accumulated by the time of clinical relapse after stopping anti-TNF agents. It is of note that $18.5 \%$ of patients had a major complication within 7 years in the long-term data from the STORI trial [31], which may not be low enough considering the status of sustained remission when IFX was stopped. Other studies also demonstrated that some cases had required surgery for the relapse following discontinuation (Table 1). Ben-Horin et al. [33] also reported 2 cases who had developed abscesses and required surgery after stopping anti-TNF agents.

\section{Risk Factors of Relapse after Discontinuation}

One of the factors reported to be associated with the risk of relapse after stopping anti-TNF is concomitant use of IM. STORI enrolled patients who were on combination therapy with IMs. A large retrospective, observational study by Casanova et al. [30] found concomitant IM therapy was significantly protective against relapse $(\mathrm{HR}=0.67$; $p=0.003$ ). This makes sense because the efficacy of IMs in maintaining remission of $\mathrm{CD}$ has been confirmed [34], and thus we could expect them to exert their efficacy after stopping anti-TNF agents from the combination therapy. However, why do not we consider stopping IMs rather than anti-TNF agents? It has been reported that stopping IM from the combination therapy with anti-TNF agents may not increase the risk of relapse especially if IM is stopped after a certain period of time [35-37]. In addition, safety concern is more apparent regarding the long-term use of thiopurines $[38,39]$. Therefore, it seems more clinically relevant to stop IMs rather than anti-TNF agents.

Low serum drug level has been also reported to be associated with a lower likelihood of relapse. Lower trough level during remission may indicate the less contribution of anti-TNF agents to the maintenance of remission, justifying its withdrawal. However, a low trough level has been also reported to be associated with the presence of endoscopically active disease in many studies [40-42]; therefore, it may not be a sole predictor for the successful discontinuation. Confirming the complete endoscopic
Kobayashi 
Table 1. Outcomes after discontinuation of anti-TNF agents in the previous studies

\begin{tabular}{|c|c|c|c|c|}
\hline Author & Study design & $N$ & Relapse rates & $\begin{array}{l}\text { Patients requiring } \\
\text { surgery after relapse** }\end{array}$ \\
\hline Domènech et al. [18] & Retrospective & 23 & $31 \%$ at 12 months & \\
\hline Wynands et al. [19] & Retrospective & 11 & $72 \%$ at 12 months & 2 \\
\hline Waugh et al. [20] & Retrospective & 48 & $50 \%$ at 477 days* & \\
\hline Steenholdt et al. [21] & Retrospective & 53 & $50 \%$ at 680 days $*$ & \\
\hline Louis et al. [22] & Prospective & 115 & $44 \%$ at 12 months & $14^{* * *}$ \\
\hline Molnár et al. [23] & Retrospective & 121 & $45 \%$ at 12 months & \\
\hline Chauvin et al. [24] & Prospective & 38 & 44 & 3 \\
\hline Dart et al. [25] & Retrospective & 9 & $33 \%$ at 12 months & \\
\hline Molander et al. [26] & Prospective & 17 & $29 \%$ at 13 months* & \\
\hline Brooks et al. [27] & Prospective & 86 & $36 \%$ at 12 months & \\
\hline Bortlik et al. [28] & Prospective & 61 & $41 \%$ at 12 months & 4 \\
\hline Kennedy et al. [29] & Retrospective & 146 & $36 \%$ at 12 months & 2 \\
\hline Casanova et al. [30] & Retrospective & 731 & $22 \%$ at 12 months & 4 \\
\hline
\end{tabular}

\footnotetext{
* Mean observation period. ${ }^{* *}$ Note that numbers of cases described in the manuscript alone are shown. It is possible that there were (1) patients who required surgery but not mentioned in the manuscript and/or (2) patients required surgery after the study period. ${ }^{* * *}$ Reported in the follow-up study published separately [22].
}

remission, probably as well as histological remission, may be necessary in such cases when considering the discontinuation of anti-TNF agents.

A recent meta-analysis with individual participant data attempted to develop a prediction model using clinical, biochemical, and endoscopic factors [43]. However, its prediction of relapse rates within a year ranges between 22 and $42 \%$ in low- and high-risk patients, which may not be sufficient to assure the successful discontinuation and make a critical decision. Taken together, there is no solid consensus on the predictors for successful discontinuation of anti-TNF agents in CD.

\section{Re-Treatment for Relapse after Stopping Anti-TNF Agents}

In general, the efficacy of re-treatment with the same anti-TNF agents for relapse after withdrawal is as high as $80 \%$ [22, 24-29, 44, 45]; however, it is still not $100 \%$. There are a few possible explanations for the reduced efficacy of re-treatment. One is a potential development of anti-drug antibodies, which is known to be more frequent when the agent is used episodically [9]. The second possible reason could be because the structural bowel damage such as strictures, fistulas, and abscesses might subclinically progress after discontinuation until the clinical relapse becomes evident. Finally, it is also possible that the present relapse may require treatment options other than anti-TNF agents, although there are only a few other out-of-class options at present for the refractory $C D$ that include anti-integrins and anti-interleukin 12/23.

\section{Potential Strategies to Avoid and Monitor Relapse}

For the response described above, a decision on stopping anti-TNF should not be made without careful discussion with patients. It may be more reasonable to stop IM but continue anti-TNF rather than vice versa if the reason for considering the de-escalation from the combination therapy is safety.

Close monitoring is absolutely necessary due to the high possibility of relapse. The risk of relapse following discontinuation seems greatest especially in the initial period (612 months) [46]. However, there is no clear evidence that recommends how the monitoring should be performed. In general, a combination of symptoms, biomarkers (e.g., Creactive protein/fecal calprotectin), and/or endoscopy/imaging is recommended [46]. A few studies demonstrated the possible usefulness of consecutive measurements of biomarkers (C-reactive protein and fecal calprotectin) in predicting the clinical relapse [30-32]; however, it is unclear if such monitoring strategy is sufficient to avoid bowel damage and/or future surgery during the interval after stopping anti-TNF until clinical relapse. 


\section{Conclusions}

Stopping anti-TNF agents may not be routinely recommended in CD patients and should be carefully discussed on a case-by-case basis taking a high risk of clinical relapse and progressive nature of disease into account. It may not be clinically relevant to easily try it because it may result in progressive bowel damage that may increase the risk of future surgery, especially in high-risk patients.

\section{Conflict of Interest Statement}

Taku Kobayashi has served as a speaker, a consultant, or an advisory board member for AbbVie, Ajinomoto Pharma, Astellas, Alfresa Pharma, Celltrion, Covidien, EA Pharma, Eisai, Eli Lilly,
Ferring Pharmaceuticals, Gilead Sciences, Janssen Pharmaceutical, JIMRO, Kyorin Pharmaceutical, Mitsubishi Tanabe Pharma, Mochida Pharmaceutical, Nippon Kayaku, Pfizer, Takeda Pharmaceutical, Thermo Scientific, and Zeria Pharmaceutical and has received research funding from AbbVie, Alfresa Pharma, EA Pharma, Kyorin Pharmaceutical, Mochida Pharmaceutical, Nippon Kayaku, Otsuka Holdings, Sekisui Medical, Thermo Fisher Scientific, and Zeria.

\section{Funding Sources}

There is no funding source regarding this manuscript.

\section{References}

1 Roda G, Chien Ng S, Kotze PG, Argollo M, Panaccione R, Spinelli A, et al. Crohn's disease. Nat Rev Dis Primers. 2020 Apr 2;6(1): 1-19.

2 Present DH, Mayer L, Braakman T. Infliximab for the treatment of fistulas in patients with Crohn's disease. N Engl J Med. 1999; 340(18):1398-405.

3 Hanauer SB, Feagan BG, Lichtenstein GR, Mayer LF, Schreiber S, Colombel JF, et al. Maintenance infliximab for Crohn's disease: the ACCENT I randomised trial. The Lancet. 2002 May 4;359(9317):1541-9.

4 Sands BE, Anderson FH, Bernstein CN, Chey WY, Feagan BG, Fedorak RN, et al. Infliximab maintenance therapy for fistulizing Crohn's disease. N Engl J Med. 2004 Feb 26;350(9): 876-85.

5 Hanauer SB, Sandborn WJ, Rutgeerts P, Fedorak RN, Lukas M, MacIntosh D, et al. Human anti-tumor necrosis factor monoclonal antibody (adalimumab) in Crohn's disease: the CLASSIC-I trial. Gastroenterology. 2006 Feb;130(2):323-33.

6 Lichtenstein GR, Yan S, Bala M, Blank M, Sands BE. Infliximab maintenance treatment reduces hospitalizations, surgeries, and procedures in fistulizing Crohn's disease. Gastroenterology. 2005 Apr;128(4):862-9.

7 Regueiro M, Schraut W, Baidoo L, Kip KE, Sepulveda AR, Pesci M, et al. Infliximab prevents Crohn's disease recurrence after ileal resection. Gastroenterology. 2009 Feb;136(2): 441-716.

8 Peyrin-Biroulet L, Van Assche G, GómezUlloa D, García-Álvarez L, Lara N, Black CM, et al. Systematic review of tumor necrosis factor antagonists in extraintestinal manifestations in inflammatory bowel disease. Clin Gastroenterol Hepatol. 2017 Jan;15(1):25-36.

9 Rutgeerts P, Feagan BG, Lichtenstein GR, Mayer LF, Schreiber S, Colombel JF, et al.
Comparison of scheduled and episodic treatment strategies of infliximab in Crohn's disease. Gastroenterology. 2004 Feb;126(2):40213.

10 Pariente B, Cosnes J, Danese S, Sandborn WJ, Lewin M, Fletcher JG, et al. Development of the Crohn's disease digestive damage score, the Lémann score. Inflamm Bowel Dis. 2011 Jun;17(6):1415-22.

11 Solberg IC, Vatn MH, Høie O, Stray N, Sauar J, Jahnsen J, et al. Clinical course in Crohn's disease: results of a norwegian populationbased ten-year follow-up study. Clin Gastroenterol Hepatol. 2007 Dec;5(12):1430-8.

12 Thia KT, Sandborn WJ, Harmsen WS, Zinsmeister AR, Loftus EV. Risk factors associated with progression to intestinal complications of Crohn's disease in a population-based cohort. Gastroenterology. 2010 Oct;139(4): 1147-55.

13 Tsai L, Ma C, Dulai PS, Prokop LJ, Eisenstein S, Ramamoorthy SL, et al. Contemporary risk of surgery in patients with ulcerative colitis and crohn's disease: a meta-analysis of population-based cohorts. Clin Gastroenterol Hepatol. 2020 Oct 27. Available from: https:// www.cghjournal.org/article/S15423565(20)31497-X/abstract.

14 Faubion WA, Loftus EV, Harmsen WS, Zinsmeister AR, Sandborn WJ. The natural history of corticosteroid therapy for inflammatory bowel disease: a population-based study. Gastroenterology. 2001 Aug;121(2):255-60.

15 Etienney I, Bouhnik Y, Gendre JP, Lémann M, Cosnes J, Matuchansky C, et al. Crohn's disease over 20 years after diagnosis in a referral population. Gastroenterol Clin Biol. 2004 Dec;28(12):1233-9.

16 Schnitzler F, Fidder H, Ferrante M, Noman M, Arijs I, Van Assche G, et al. Long-term outcome of treatment with infliximab in 614 patients with Crohn's disease: results from a single-centre cohort. Gut. 2009 Apr 1;58(4): 492-500.

17 Qiu Y, Chen B, Mao R, Zhang S, He Y, Zeng $Z$, et al. Systematic review with meta-analysis: loss of response and requirement of anti$\mathrm{TNF} \alpha$ dose intensification in Crohn's disease. J Gastroenterol. 2017 May 1;52(5): 535-54.

18 Domènech E, Hinojosa J, Nos P, Garcia Planella E, Cabré E, Bernal I, et al. Clinical evolution of luminal and perianal Crohn's disease after inducing remission with infliximab: how long should patients be treated? Aliment Pharm Ther. 2005;22(11-12):110713.

19 Wynands J, Belbouab R, Candon S, Talbotec C, Mougenot J-F, Chatenoud L, et al. 12-Month follow-up after successful infliximab therapy in pediatric crohn disease. J Pediatr Gastroenterol Nutr. 2008 Mar;46(3): 293-8.

20 Waugh AWG, Garg S, Matic K, Gramlich L, Wong C, Sadowski DC, et al. Maintenance of clinical benefit in Crohn's disease patients after discontinuation of infliximab: long-term follow-up of a single centre cohort: Longterm remission after discontinuation of infliximab. Aliment Pharm Ther. 2010 Nov; 32(9):1129-34.

21 Steenholdt C, Molazahi A, Ainsworth MA, Brynskov J, Østergaard Thomsen O, Seidelin JB. Outcome after discontinuation of infliximab in patients with inflammatory bowel disease in clinical remission: an observational Danish single center study. Scand J Gastroenterol. 2012 May;47(5):518-27.

22 Louis E, Mary JY, Vernier-Massouille GG, Grimaud JC, Bouhnik Y, Laharie D, et al. Maintenance of remission among patients with Crohn's disease on antimetabolite therapy after infliximab therapy is stopped. Gastroenterology. 2012 Jan;142(1):63-e31. 
23 Molnár T, Lakatos PL, Farkas K, Nagy F, Szepes Z, Miheller P, et al. Predictors of relapse in patients with Crohn's disease in remission after 1 year of biological therapy. Aliment Pharmacol Ther. 2013;37(2):225-33.

24 Chauvin A, Le Thuaut A, Belhassan M, Le Baleur Y, Mesli F, Bastuji-Garin S, et al. Infliximab as a bridge to remission maintained by antimetabolite therapy in Crohn's disease: a retrospective study. Dig Liver Dis. 2014 Aug;46(8):695-700.

25 Dart RJ, Griffin N, Taylor K, Duncan J, Sastrillo M, Sanderson J, et al. Reassessment of Crohn's disease treated with at least 12 months of anti-TNF therapy: how likely is treatment withdrawal? Frontline Gastroenterol. 2014 Jul;5(3):176-82.

26 Molander P, Färkkilä M, Salminen K, Kemppainen $\mathrm{H}$, Blomster $\mathrm{T}$, Koskela R, et al. Outcome after discontinuation of TNF $\alpha$-blocking therapy in patients with inflammatory bowel disease in deep remission. Inflamm Bowel Dis. 2014 Jun 1;20(6):1021-8.

27 Brooks AJ, Sebastian S, Cross SS, Robinson K, Warren L, Wright A, et al. Outcome of elective withdrawal of anti-tumour necrosis factor- $\alpha$ therapy in patients with Crohn's disease in established remission. J Crohns Colitis. 2017 Dec 4;11(12):1456.

28 Bortlik M, Duricova D, Machkova N, Hruba V, Lukas M, Mitrova K, et al. Discontinuation of anti-tumor necrosis factor therapy in inflammatory bowel disease patients: a prospective observation. Scand J Gastroenterol. 2016 Feb;51(2):196-202.

29 Kennedy NA, Warner B, Johnston EL, Flanders L, Hendy P, Ding NS, et al. Relapse after withdrawal from anti-TNF therapy for inflammatory bowel disease: an observational study, plus systematic review and meta-analysis. Aliment Pharmacol Ther. 2016;43(8): 910-23.

30 Casanova MJ, Chaparro M, García-Sánchez V, Nantes O, Leo E, Rojas-Feria M, et al. Evolution after anti-TNF discontinuation in patients with inflammatory bowel disease: a multicenter long-term follow-up study. Am J Gastroenterol. 2017 Jan;112(1):120-31.
31 Reenaers C, Mary JY, Nachury M, Bouhnik Y, Laharie D, Allez M, et al. Outcomes 7 years after infliximab withdrawal for patients with Crohn's disease in sustained remission. Clin Gastroenterol Hepatol. 2018 Feb;16(2):234e2.

32 Peyrin-Biroulet L, Sandborn W, Sands BE, Reinisch W, Bemelman W, Bryant RV, et al. Selecting therapeutic targets in inflammatory bowel disease (STRIDE): determining therapeutic goals for treat-to-target. Am J Gastroenterol. 2015 Sep;110(9):1324-38.

33 Ben-Horin S, Chowers Y, Ungar B, Kopylov U, Loebstein R, Weiss B, et al. Undetectable anti-TNF drug levels in patients with longterm remission predict successful drug withdrawal. Aliment Pharm Ther. 2015;42(3): 356-64.

34 Khan KJ, Dubinsky MC, Ford AC, Ullman TA, Talley NJ, Moayyedi P. Efficacy of immunosuppressive therapy for inflammatory bowel disease: a systematic review and metaanalysis. Am J Gastroenterol. 2011 Apr; 106(4):630-42.

35 Van Assche G, Magdelaine-Beuzelin C, D'Haens G, Baert F, Noman M, Vermeire S, et al. Withdrawal of immunosuppression in Crohn's disease treated with scheduled infliximab maintenance: a randomized trial. Gastroenterology. 2008 Jun;134(7):1861-8.

36 Oussalah A, Chevaux J-B, Fay R, Sandborn WJ, Bigard M-A, Peyrin-Biroulet L. Predictors of infliximab Failure after Azathioprine withdrawal in Crohn's disease treated with combination therapy. Am J Gastroenterol. 2010 May; 105(5):1142-9.

37 Hisamatsu T, Kato S, Kunisaki R, Matsuura M, Nagahori M, Motoya S, et al. Withdrawal of thiopurines in Crohn's disease treated with scheduled adalimumab maintenance: a prospective randomised clinical trial (DIAMOND2). J Gastroenterol. 2019 Oct;54(10): $860-70$.

38 Siegel CA, Marden SM, Persing SM, Larson RJ, Sands BE. Risk of lymphoma associated with combination anti-tumor necrosis factor and immunomodulator therapy for the treatment of Crohn's disease: a meta-analysis. Clin
Gastroenterol Hepatol. 2009 Aug;7(8):87481.

39 Kandiel A, Fraser AG, Korelitz BI, Brensinger $\mathrm{C}$, Lewis JD. Increased risk of lymphoma among inflammatory bowel disease patients treated with azathioprine and 6-mercaptopurine. Gut. 2005 Aug 1;54(8):1121-5.

40 Imaeda $\mathrm{H}$, Bamba S, Takahashi K, Fujimoto T, Ban H, Tsujikawa T, et al. Relationship between serum infliximab trough levels and endoscopic activities in patients with Crohn's disease under scheduled maintenance treatment. J Gastroenterol. 2014 Apr;49(4):67482.

41 Koga A, Matsui T, Takatsu N, Takada Y, Kishi M, Yano Y, et al. Trough level of infliximab is useful for assessing mucosal healing in Crohn's disease: a prospective cohort study. Intest Res. 2018 Apr;16(2):223-32.

42 Chaparro M, Barreiro-de Acosta M, Echarri A, Almendros R, Barrio J, Llao J, et al. Correlation between anti-TNF serum levels and endoscopic inflammation in inflammatory bowel disease patients. Dig Dis Sci. 2019 Mar; 64(3):846-54.

43 Pauwels RWM, Janneke van der Woude C, Nieboer D, Steyerberg EW, Casanova MJ, Gisbert JP, et al. Prediction of relapse after anti-tumor necrosis factor cessation in Crohn's disease: individual participant data meta-analysis of 1317 patients from 14 studies. Clin Gastroenterol Hepatol. 2021 Apr.

44 Dai C, Liu WX, Jiang M, Sun MJ. Mucosal healing did not predict sustained clinical remission in patients with ibd after discontinuation of one-year infliximab therapy. PLoS One. 2014 Oct 20;9(10):e110797.

45 Gisbert JP, Marín AC, Chaparro M. The risk of relapse after anti-TNF discontinuation in inflammatory bowel disease: systematic review and meta-analysis. Am J Gastroenterol. 2016 May;111(5):632-47.

46 Doherty G, Katsanos KH, Burisch J, Allez M, Papamichael K, Stallmach A, et al. European Crohn's and colitis organisation topical review on treatment withdrawal ("exit strategies") in inflammatory bowel disease. J Crohns Colitis. 2018 Jan 5;12(1):17-31. 